\title{
DEFENSIBLE URBAN SPACE IN BAHRAIN
}

\author{
Ashraf M. Soliman ${ }^{1}$, Hamad Juma Al- Fazari ${ }^{2}$ \\ ${ }^{1}$ Assistant professor in Architectural Engineering Department, Minia University, Egypt, and Chairman of Interior \\ Design Department Kingdom University, Bahrain \\ ${ }^{2}$ Head of Engineering \& projects affairs section, Southern Governorate, Bahrain
}

\begin{abstract}
All defensible urban space design has a common purpose, which is to restructure the physical layouts of communities to allow residents to control the areas around their buildings by natural surveillance. Those physical layouts include buildings, streets, grounds outside their buildings, the walkways, lighting poles, drainages and all the infrastructure facilities, which may help people to improve their local neighborhoods. This paper concentrates on the defensible urban space design in the neighborhoods particularly in Bahrain either in the privately owned neighborhoods or in neighborhoods with government ownerships. The research first examines the theoretical aspects and theories and design principles related to neighborhood design with emphasis on elements such as walkways, buildings layouts, road networks, building's entrances and other important elements. Those elements can be designed to help create safe and secure neighborhoods. This first part of the research reviews the theoretical background on defensible urban space design forming a basis to analyze and evaluate the built environmental elements in the case studies. In the second part of the research, these ideas are applied by means of a descriptive and questionnaire survey. In the descriptive analysis, the research looks at safety and security prevailing in residential built environments of Bahrain. It focuses on different built-environmental aspects which can be considered to lead to safety problems. In addition, the questionnaire survey looks at the ways in which the Bahrain community assesses the security situation. By these means, it identifies the factors that negatively affect the sense of security in residential settlements of Bahrain. Finally, the research produces a set of conclusions and recommendations to help improve the urban planning process followed by the governmental agencies, towards creating a safe Bahraini community.
\end{abstract}

Keywords: Defensiable space, Security, Safety, Territoriality, Vandalism

\section{INTRODUCTION}

"The proper design and effective use of the built environment can lead to a reduction in the fear of crime and the incidence of crime, and to an improvement in the quality of life" Jeffery 1990, as cited in Crowe, D. 2000: P1)

Kingdom of Bahrain pays a great deal of attention to provide security and safety to its citizens and help them live comfortably while fulfilling their religious, social, cultural, educational and other needs. It is keen to provide a peaceful environment for people, and also project to the world an image of a quiet life enjoyed by its citizens. Safety and security are fundamental human needs, According to Maslow (Makarova, 2009) Safety and security is the second most significant out of five fundamental needs related to all aspects of human life. It is accepted that the environment plays a major role in providing it. Therefore, architects and plannerss have an important role and responsibility to provide a safe and secure environment so that all people can live without fear. Designing spaces is critical for this task, because what planners and designers do may or may not produce 'defensible' urban spaces that support such feelings. Often, spaces created without considering safety can promote opportunistic crimes that can contribute to a sense of fear. Defensible spaces are different. They are those their residents can oversee and therefore can defend against unwanted intruders. Most importantly, they are spaces where people feel safe.
Designing defensible urban spaces has the primary objective of organising physical layouts of neighbourhoods to enable the residents to take control of the spaces. These may include their homes and immediate surroundings such as roads and streets or alleyways and public spaces. Design can either enable or hamper people's taking possesssion of those areas where there are great potentials to sustain their lifestyles. When such spaces do not have the characteristics of defensibility, people will feel unsafe and they can indeed be unhappy.

Defensible urban spaces promote self induced safety rather than having it been brought about by external forces such as municipalities or states.. Spaces remain safe even if the state is not present through policing. In fact, defensible spaces depend on characteristics of space to discourage anti-social activities and criminal tendencies to manifest in the builtenvironment. Moreover, such spaces may also bring people of different social and economic standings to come together. This is more so in low-income communities where people depend upon each other for common good, which includes safety. Such urban spaces can bring about communal harmony and opportunities to expose the economically deprived to the other so that they understand each other and naturrally construct self supporting social networks. 


\subsection{Definitions}

- Defensible space: the environments that will discourage crimimal activities taking place by enabling people to defend its spaces by easy surveyalance.

- Territoriality: the idea that people have a sense of ownership over geographical spaces that does not necessaily legally belong to them; particularly around where they live.

- $\quad$ Natural surveillance: This refers to the possibility the physical characteristics of a space afford to people to oversee what is happening.

- Image: the visual impression created by a space, thing or an event.

- Milieu: refers to the physical setting in which people live and do things.

- Defense: this is the idea of taking what ever actions necessary to protect oneself against someone else's offensive act.

- Urban means an area which is heavily built-up is occupied by a higher density of people; The community depends on mechanical production, rather than agriculture.

- Security: the idea of being protected by aggressive or unacceptable acts of others.

- $\quad$ Safety the idea of being prevented from being subject to bodily harm.

- Vandalism refers to the acts of deliberately destroying or damaging property belonging to others, especially public property without a jutifiable reason

\subsection{Research Problem}

The present situation of planned settlements in Bahrain shows clear signs of problems likely to arise in the future. On the one hand, these relate to a lack of properly designed public social spaces. Onthe other there is an inadequacy of unobtrusive surveillance available. The decision makers are often unaware of the likely social problems or negative behavior prompted by them. There remains an absence of constant revision and updating of rules and regulations pertaining to urban design and these are likely to result in unexpected urban problems connected to builtenvironments. Following summarizes these urban problems:

a) Conflicting distribution of communities: $70 \%$ of the foreign labourers live in popular residential areas of the locals, which lead to complex social problems. Statistics illustrate the issues (Bahrain, 2010).

b) Likely repetition of disasters, such as the fire which occurred at the living quarters of foreign labourers who had occupied an overcrowded residence. More than 30 labourers died in an incident that happened in the capital Manama, in January 2013.

c) Inadequate emergency access: The old narrow roads in traditional neighborhoods characterized by inadequate roads cannot be accessed by emergency vehicles, in case of fires, social and civil unrest and other such disasters.
The prevalence of these issues demonstrates the need for this research. It shows that comprehensive research examining the relationships between safety and security of communities and the environment are needed to find solutions for creating safe and secure neighborhoods.

\subsection{Research Objectives}

The research aims to achieve the following four main objectives:

- To provide security conservation through environmental design.

- To minimize negative aspects affecting security and safety of the community by finding appropriate integrations between the various government agencies and the authority of planning and urban development.

- To explore architectural concepts that may be employed to enable communities to provide safety and security by themselves.

- To contribute to the reduction of social security problems of the neighborhoods which threaten individuals, whether local citizens or expatriate residents by creating simple and implementable ideas in the planning and design stages.

\subsection{The Research Methodology}

To achieve the objectives of this research, it employs descriptive statistics and correlation methodology as follows:

- Obtaining images to illustrate the current situation in different residential locations and using a descriptive methodology for analysis.

- Collecting and analyzing plans and satellite images of settlements and neighborhoods to apply the defensible urban space concept, and descriptive methodology.

- Administering a questionnaire to residents to ascertain information on their life styles, and using a descriptive methodology to assess the current situation of security and safety in the neighborhoods.

- Collecting statistical tables \& graphs from the Central Information Organization and using the correlation methodology to analyze them. In addition, an analytical comparison of the study areas is done for different residential blocks in Bahrain to uncover the effects of urban planning on safety and security. 


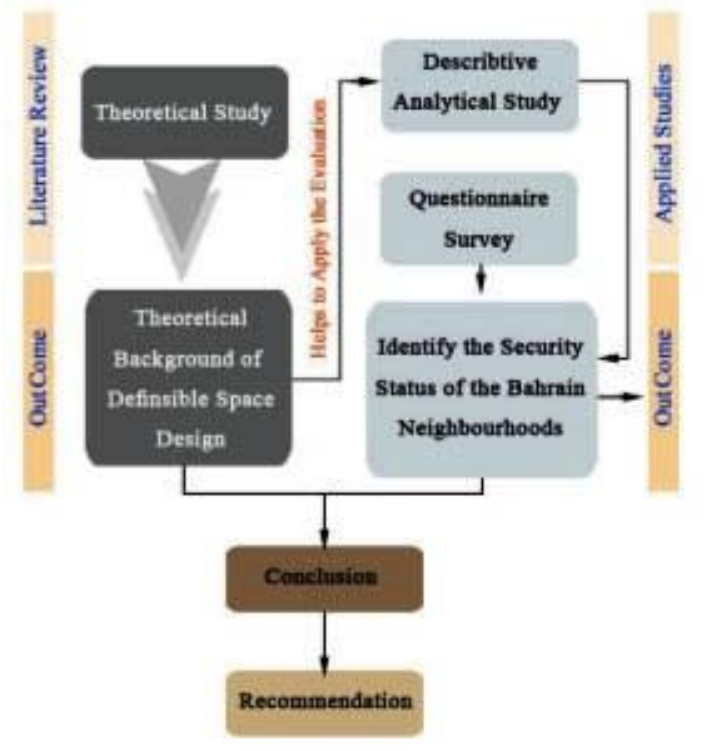

Fig 1 shows the research methodology

\section{LITERATURE REVIEW (THEORETICAL BACKGROUND)}

"People to realize that the most secure neighborhoods are also very likeable and comfortable to live in." (Marcus Felson, Rachel Boba, 1947, p. 147). Defensible space is a theory proposed by architect and city planner Oscar Newman as far back as 1972. It emerged from the examination of issues surrounding the demolition of the Pruitt Igoe housing project in Ivanhoe which was initially hailed as one of the master pieces of Modern Architecture. However, it eventually succumbed to an uncontrollabel level of crime. Newmann argued that this was because residents in the Pruitt Igoe high rise neighborhoods had no control over its public spaces such as corridors and lift lobbies and these facilitated the criminals to take control of space. Newman while presenting the idea of defensible space argued that social control was an essential pre-requisite for crime prevention, particularly in community spaces. He says, "defensible space is defined as a term used to describe a residential environment whose physical characteristicsbuilding layout and site plan-function to allow inhabitants themselves to become key agents in ensuring their security. (wikipedia, Defensible_space_theory, 2013).

He argues that a space is defensible only if it posseses such characteristics, and that good design must invest them in space. Newman further argues that "Defensible space therefore is a socio-physical phenomenon," (wikipedia, Defensible_space_theory, 2013). This means that a builtenvironment alone cannot prevent crime but both people and physical characteritsics of a space are parts of a good defensible built-environment. Undeniably, a space is safer when people do have ownership and responsibility for that space. In such situations of defensible space, "the criminal is isolated because his turf is removed" (Newman, 1972). In other words, if an intruder feels that he is being watched, he is unlikely to commit any crime or even vandalism. The theory of defensible space proposes that vandalism and crimes can be suppressed by good design; in other words, through environmental design.

\subsection{Factors that make a Defensible Space}

\subsubsection{Territoriality}

The idea that one's home is sacred. "Territory... is valued for the way it facilitates making sense, for the opportunity for choice and control it provides, as well as for the many positive associations it comes to have."'(Gifford, R. 2001, p. 149).Territoriality is the feeling of sense of control a person has over an area of space that whether it legally belongs to or not. Robert Ardrey's developed the idea by observing animal behaviour, and later pointed out that it can be applied to human beings as well. People see some spaces over which they must have controlling power, and then go on to defend them against intruders. Sense of community emanates from territoriality and those who feel a sense of community over some spaces are more likely to act against the presence of outsiders in such a space. Understanding theritoriality helps design to be utilised to construct real and symbolic barriers to articulate the concept across space. In housing estates, families often possess this sense of territoriality over the entryway and will act aginst the unauthorised outsiders being present there. Neighbours who live next to each other will share the territories and collectively exercise such control (Remy, 2013) whereby a senseoof safety will be constructed.

\subsubsection{Natural Surveillance}

this refers to the availability of a residents' effortless ability to see what is happening over a space (Ocsar Newman, 1972). Spaces with natural surveylance are safer from crime or vandalism. In fact, more the number of observers, there is the probability that an offender would be seen in the act. This will deter crime and improve safety.

\subsubsection{Image}

his refers to the ability a building has in conveying an image to spectators about the nature of care and attntion it receives from its occupants. The 'images' they produce convery messages and others will read them. For example, a well-kept building gives the impression that the occupants care and look after the building and its surroundings. In such a situation, the likely offenders will be deterred or dicourages by the visual cues given by the image. Wilson's Broken Windows Theory "Ocsar Newman, 1961" explains this well. It says that if a window is broken in a building, and remains unattended to, its image tells the others that no one cares for the building. It is likely that more windows may be broken, and offenders may be tempted to see the place as a potentially easy target. In other words, a place that shows being well-looked after by the occupants is less likely to be vandalized (Remy, 2013). 


\subsubsection{Milieu (Safe Zones)}

this refers to a number of different aspects; first, it is to do with the location being in a safe zone. An example would be a location close to a police station. A safe zone inherently provides a secure environment fo rmany buildings in the locality (Jeffery, 1990).Moreover, Newman suggested that clear demarcations between the private, public, and semipublic space must be constructed in residential environments. According to him, that would increase privacy of spaces and make it a defensible space (Newman, 1972). Implied surveylance and control is central to this theory. It means that the millieu or the setting itself has the ability to either foster or inhibit crime. These informal social controls will effortlessly create defensible urban spaces and will result in the reduction of crime or vandalism ( Remy, 2013)

As can be seen, the concept of defensible urban space is complex and has led to controversies too. In United States for example, Department of Justice experiment in Hartford, Connecticut closed streets and assigned police teams to the neighborhood, and brought new public housing projects designed around ideas of limited access to the city. However, Hartford did not show any dramatic drop in vandalism. In comparison, the private places of St. Louis has much lower crime than public streets. Perhaps, this canbe explained by looking at the politics in the two places. In St. Louis, people had the capacity and incentives to defend their urban spaces. Moreover, people have the right to ask an un-invited individual to leave their street around private spaces, because they they tend to have a sense of belonging over such a space. However, a public street is public by definition, and no one can oversee or ask to move away from a member of the public. (wikipedia, Defensible space theory, 2013).

\subsection{Application and Reflections of the Theory}

Newman's theory of Defensible Space had great appeal in the 1970s. However, since 1980's its impact has diminished. Nevertheless, its relevance to the safety of the builtenvironment cannot be ignored.

A review of recent research show that at present not many refer to the concept (American Society of Criminologists and the American Criminal Justice Society) It had been intermittantly referred until about 1993 and 1995. In other words, its popularity had peaked around 1970's and first half of the 1980's. However, Oscar Newman' theory, work and projects are still available to the public through the internet. Although it seems to have lost appeal in criminological research, the environment-behaviour reserachers see that public space scan benefit immnsely from the ideas. In fact, its relevance is to the designers; the architects planners and urban designers.

Newman's theory helps built-environment professionals to work out design strategies related to streets. Its main tenet is 'closure' which can be articulated in terms of creating culde-sacs which provide a relatively secluded envieonmen.
Cul de-sacs can easily be naturally surveyed. In some cases, planners have used the idea to place obstacles across road intersections, in order to create residential loops. Although these strategies have not necessarily reduced crime rates as expected, they do improvement the sense of safety experienced by people. Many argue that a visible drop in crime or vandalism is not necessary to claim the value of the strategy. These characteristics may prompt changed behaviour and help produce more stable neighborhoods with less crime or vandalism. After all, crime is not entirely environment-driven.

The most significant outcome of these ideas however is "natural variations" now present in many environmental settings. However, it would be useful to ascertain if these differences in environmental settings have any influence on crimes at all. The case in point is James Q. Wilson's, theory, "Broken Windows" which shows how crime or vandalism is directly related to the physical conditions of a builidng or an image of a neighborhood. In this sense, the planners have to ask how the neighborhood character can be naturally allowed to emerge as one of a caring society, who will 'fix the broken windows'. In this way, the likely offenders may take their eyes off the neighborhood. If the window was not replaced, then eventually, the residents of the neighborhood would become more fearful of potential crimes, and will also mistrust other residents. Streets could be deserted enabling more offenders to be attracted to the area. There are good examples of these having happenned across the world. For examplle, Benwell in Newcastle was a crime ridden area that is a classic example of the evolution of a neighbourhood through the 'broken window'.

Newman's theory although very deterministic was influential in the development of a series of other theories. In fact, a lot of projects aimed at preventing vandalism followed the theory. For example, 'Situational Crime Prevention' is based on the same ideas although it does not refer to Newman formally. It looks at the idea of 'opportunity' as a variable in the environment which an offender must recognise and make his calculations in order to offend. In so doing, it proposes to minimise such opportunties as well as eleminate the likely rewards an offender can get. This theory has helped reduce various types of criminal activities in specific places, while generally also taking away some of the pleasant and design characteristics of the environments looking urbanization and modernization proposed a model of social change. She argued that as an inherent outcome urban development led to increased crime. Although violent crimes do occur in rural areas urbanization, brings about property related crimes (Jeffery, 1990). This was because, urbanity also created strangers, led to high density built-up spaces and created conditions to create criminals as wellas places for committing crime.

'Crime Prevention through Environmental Design' was a program that came through the application of Oscar Newman's theory on Urban Design. In 1985. For example, Remy, (2013) discusses how a project in Tallahassee was 
launched to deal with crimes often commiutted in that areas aroudn convenience-stores. Numerous other places have also been subjected to similar programs. Gainesville is another example. Alice Coleman was active in London working on crime prevention through environmental design. She identified a number of crime-ridden neighbourhoods in London and devised planning schemes to eliminate opportunities that prevailed there thus reducing crime rates.

A lot of devices to prevent crime have also been invented that employes the ideas of Newman; Surveylance cameras. Social programs have also been launched such as 'neighborhood watch' which are enow practiced arouhed the world (Jeffery, 1990). Wolfer and others (1999) shows how the problem is being looked at by the police in terms of crime prevention. Police now use 'hot spot analysis', and 'crime prone areas'to ascertain if an area has a characteristic that prompts crime. (Wolfer, Baker, \& Zeezza, 1999) Indeed, these show that Newman's basic ideas of defensible space have far reaching usefulness not just for urban designers and planners but the society as a whole. Some agencies have gone a lot further than design strategies and projects. Housing and Urban Development (HUD) in United States - employs Newman's theory in evaluating projects before they are implemented. They go further and decide which building sar eto be demolished in response to crime and vandalism. It is because these ar easpect sthat quality of life of people particularly in urban areas.

To sum up, Newman's theory although now not popular in criminology has a major influence in the design of the built environment. Crime Prevention through Environmental Design (CPTED) employs three main strategies. These are(1) natural surveillance, (2) natural access control, and (3) territorial enforcement. These strategies are articulated into fencing and curbs, good illumination, well-lit walkways, and the distribution of play equipment and other things to improve the appearance of a neighbourhood. Moreover, mini-neighborhoods are created by enclosure so that a greater sense of community can becreated. People's increased awareness as well as participation in everyday life in surveying their surrounding for clues have been popularised.

On the whole, Newman's defensible space theory has been an enormously meaningful one that has had significant influence upon the way in which urban environments are now designed and policed. Once extremely popular, it has been less-cited recently, although its basic tenets are unchallengeable and has validity even today. As Remy (2013) shows, Oscar Newmann and his theory remains the most critical and relevant theoretical approach to understand and create safe environments by means of crime prevention through environmental design

\subsection{Design Principles of defensible Urban Space}

A "good" land use plan with "good" implementation produces a "good" built environment. What is built, where it is built, and when and how it is built are critical questions whose answer depend upon many actors, each with different definitions of what is good.

Design and Planning of built-environments is a complex process. Although planning is an every day activity of people, It is also required to take to complex decisions by government agencies, industries and businesses. IN the built-environments, this means toi allocate land for suitable activities based on the needs of people, visions of the states and geographies of lands. They are controlled by economic realities and rules of a country although planning inadvertantly affects both rules and regulations as well as economics. Planning is based on information about activities which are carried over to logical, and systematic decision-making conclusions in order to take proper actions (Litman, 2011). Planning should be,

- Comprehensive - This means to look at all scenarios and explore all possibilities and options.

- $\quad$ Efficient - This means they should be carried out promptly and without wastage of resources and time.

- Inclusive - This means to include all people from rich to poor and all aspects from geography to economics.

- Informative - This means the decisions must be explained with justifications.

- Integrated - This means to have good relations between short term expectations andlong term achievements.

- Logical - This means that decisions must be based on step by step progression of arguements.

- Transparent - This means that the proces smust be open and available for scrutiny.

There are a number of principles of designing defensible spaces. They are as follows.

1. Rsidential environments for eople must be assigned specific environments that are suitable to them so that they can control space. Areas are best decidesd on the basis of family structures, ages, life-styles, social status, incomes, and in general backgrounds.

2. In residential developments, the territories must be allocated to define space to reflect the areas of influence required by people. Areas should be demarcated as zones so that people living nearby can easily engage in natural surveying.

3. In house design, interiors must open to exterior spaces through windows so that residents can naturally survey the outside environments of their houses.

4. Entrances to houses must be located in such a related to streets to incorporate the public spaces as a territorial area of houses. The residents then can watch over space.

5. Building forms and language of architecture should not suggest that some people are excluded or the area is of a poor residents and so on. In other words, the images should not convey stigmatized characters. 
6. To create defensible urban spaces, residential areas should be couched into smaller areas occupied by families who can form communities. This will enhance control. Smaller groups of families take greater responsibility and care. Larger communities tend to break into smaller groups. People often use areas that have been designed for them, and this will ensure that the spaces are used. These will bring about a feeling of sense of belonging that naturally evolves into looking after the spaces. Comared with this, if larger groups are around a common space, no one will know who has control over the area, and the space is unlikely to be fully usable. Disagreements and disputes are comon in such spaces (Newman, 1996)

7. Walkability It is advisable always if possible to place activities within areas of short walks from home. Streets and walkways that are pedestrianfriendly help a great deal. This means buildings houses close to the streets with porches overlooking. A street with houses that have windows \& doors and have trees to shade and comprised of on-street parking are very user friendly streets. If possible, creating streets without cars can greatly enhance defensible streets.

8. Connectivity: This is connected with walkability. When streets are interconnected, the grid networks help distribute traffic and eventually help people walking. Pleasurable walking areas involve a combination of narrow walkways, boulevards, and alleys whixch must be carefully created.

9. Mixed-Use \& Diversity: Defesible spaces are also benefit having a mix different activities such as shops, houses and other facilities. These will bring a diversity of people and will ensure that the plac eis always frequented by people.

10. Mixed Housing: It is advisable to create mixture of different types of houses, with varying sizes in a neighbourhood to help diversity.

11. Quality Architecture \& Urban Design A design should look for creating beauty as well as human comforts, and spirit of place. These must be integrated to design from the beginning and contribute a neighbourhood with architecture of human scale. Needless to say beautiful surroundings create joyful places.

12. Traditional Neighborhood Structure: Urban design and planning should as far as possible learn lessons from and follow the structure of the traditional neighbourhoods. This means to have a recognisable center and a periphery. The center must comprise of the public spaces so that the public realm is given its due importance. Such spaces must contain opportunities for public art and should have many opportunities for a variety of activities. The areas must be preferably accessible by walking. The central area must also have the possibilities for high densities slowly moving towards less densities at the periphery. This is an idea known as 'transect' which is an analytical system. It means to provide elements that mutually reinforces each other in order to produce a series of natural and urban settings. It brings togeher techniques of environmental assessment with techniques of community design zoning. The system ensures that both the natural and the man-made environments are taken together. It helps the assessment of the human settlements as relevant to people while also enables Nature to contribute. According to Bacon, E. (1969), this helps creating a hierarchy of streets for each area.

13. Increased Density: when buildings are closer together, they help people to walk and simultaneosuly help services and resources to be used more efficiently. Inevitably, places created are more convenient and enjoyable. The ideas of 'new urbanism' suggest that density principles should be applied from small towns to large cities.

14. Green Transportation: a city must work towards producing a network of sustainable transport systems connecting the neighborhoods and across cities. These should include trains, bicycles, scooters, and walking as daily transportation. As said before, pedestrian-friendly design encourages defensible space.

15. Sustainability: this has now become a basic principle of planning and involves doing things with minimal environmental impact. As known, planning should promote ecologically sensitive technologies, and return to natural systems as far as possible. Dependancy on fossil fuels must be reduced and energy should be efficiently used. Development must relate more to locality while driving is reduced and walking facilitated.

16. Quality of Life As Bacon, E (1969) put it, all the above principles collectively contribute to a high quality of life. They help create enriching, uplifting, and inspiring places in which people will lead happy lives.

\subsection{Defensible Space Benefits}

\subsubsection{A. Benefits to Residents}

The most meaningful infleunce benefit defensible spaces has is upon the residentswho live in such neighbourhoods. First and foremost, this helps cerate a sense of safety that will greatly enhance the quality of life. This means that where people live will be better. The work places will be safer, and people will work more efficiently focused on what they do instead of having to worry about safety. People in fact will be discouraged to take employment in areas where working is unsafe. Similarly, children will benefit greatly. The play spaces will be safe and children will be able to use them happily without their parents having to worry. This also means that the property values will be stable if not go up. It will be possible for people to walk and this means there will be less driving and less traffic congestion. This will also mean healthier lifestyles with more walking and less stress. Defensible spaces have a great impact on the general urban developmen of a region. Main streets, bike trails, parks, and 
Nature can be amalgamated for their own benefit without having to eliminate tree cover and bushes. Pedestrian friendly walkways in theneighborhoods and towns generally improve the appeal of an area. These result in meaningful relationships among people could lead to friendlier communities and the neighbourhodds will develop great communities. Indirect benefits are un-estimatable. Defensible space urbanism also creates greater economies and contain urban sprawl. People and architecture could be in harmony and result would be great architecture The most significant advantage however, as Bacon, E. (1969) put it, is the availability of more open spaces for people. A neighbourhood will be an enjoyable space.

\subsubsection{Benefits to Businesses}

Defensible spaces also endow advantages to businesses. If people walk often, foot traffic instead car traffic will increase sales.If people spend less on cars and petrol, then it is likely that they will have more money to buy other things and have money for leisure. Businesses do not need to clamour to advertise to get customers because they are there. Thus profits will increase with less advertising costs. These will improve the envoironment because there will be few large sign posting polluting the visual appeal.

If people have better lifestyles and healthier ways of living, invariably it could save a lot for the people and medical expenses. A community less stressful is a great community. Businesses do not have to spend loads of money on safety such as installing cameras, employing security guards and can save greatly on trying to improve safety. Goods in stores will be safer and will have no insurance costs. Infact, insurance premiums will come down saving the business enormous amounts. Defensible spaces are likely to prompt the emergence of smaller shop keepers with smaller shops and spaces promoting small local businesses. A neighbourhood will indirectly benefit with the incubation of new businessmen. Indeed, the properties will have less costs in terms of renting and easier general upkeeping. These effects reverberate acoss all businesses bringing about healthier businesses and people. Cities will be lively with more people walking, shopping and eating at restaurants. As Bacon, E (1969) put it, this means the communities will know each other, socialise and progress collectively with the buisiness community who will be part of the neighbourhood itself.

\subsubsection{Benefits to Developers}

Defensible spaces accrue benefits to the developers without difference. First of all, neighbourhoods with defensible spaces are safe and thus property values will go up withincreasing demand. More people will want to more and there could be a hive of economic activity. Itis also likely that new developments and new investments will hapen, because the area will appeal to deveopers. Developments will be easier with safety. Because, work sites will not be robbed and insurances will remain affordable. Without vandalism, developments can progress smoothly without having to worry about the issues of petty crimes. With more people walking, provision of secured car parking will not be a necessity. These usually add to developmental costs. What thesem mean is that good dvelopments will always happen in such neighbourhoods either at a big scale or small scale where residents will live longer and invest in their properties. In fact, developers are likely to see a hive of activities in such neighbourhoods all the time. As Bacon, E (1969) put it, he residents will be consumers with buying power and desire to invest in homes and businesses promoting development.

\subsubsection{Benefits to Municipalities}

Without doubt, state agencies and municipalities greatly benefit from defensible space urbanism. First and foremost, a stable and safe neighbourhood enhances the profile of the municipality ward. It ensures a good community of residents who are willing to invest and pay tax for their properties. This means that the municipality will have a stable tax base. If the areas are well kept and there is no vandalism, then public properties will be safe. The municipality can then concentrate on less expenditure on infrastructure and utilities instead of constantly battling to upkeep maintaenance. Most importantly, costs on law and order and policing will be minimal. When urban development takes place, the tax base increases too. When buildings are packed into a tighter area, and walkability persists, areas will be even safer and have less crime. Municipalities do not have to worry about upkeep because the residents themselves will take care of these. In other words, the people love their places and look after the neighbourhoods. Municipalities will have communities who are less angry and less resistant towards the municipality but look up to the municipality for progress. Overall, the community image and municipality image will be improved together as a great partnership. Indeed, the neighbourhoods they possess will be of great places. As Bacon (1969 put it, the greatest benefit would be in the positive civic involvement in the development of the area and in the government.

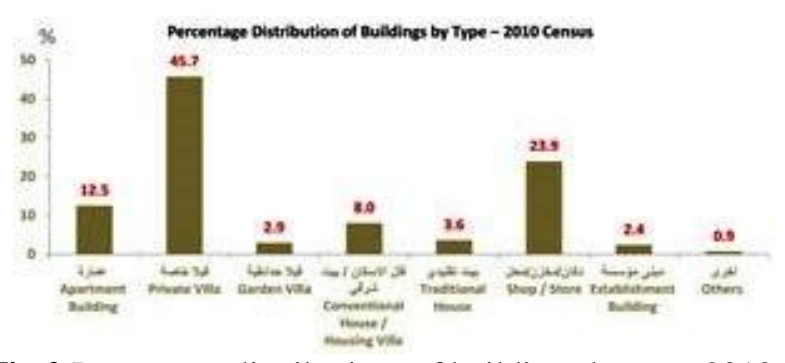

Fig 2 Percentage distributions of buildings by type-2010 Census

Source:http://www.cio.gov.bh/cio_ara/English/Publicatio ns/Census/Buildings14_2_2011.pdf

\section{APPLIED STUDY}

\subsection{Introduction}

The main aim of the study is to ascertain the resident's feelings and opinions pertaining to the status of safety in the neighborhoods under study. This helps the researcher to 
assess the level of the defensibility of space as has been designed including spaces and road networks and to understand how the residents react to their environment. This study is focused on residential neighborhoods with different tissue and land use in a number of different Bahraini governorates. The following methodology of the applied study adapted to descriptive analytical study of the current status of Bahrain urban spaces and community survey study using a questionnaire in order to verify the safety factors as prevalent in the residential areas in Bahrain.

\subsection{Descriptive Analytical Study}

The study aims to define the current security situation in Bahrain. It is based on observations of different aspects such as the security problems resulting from the population characteristics, housing, road networks, threat sources and environmental issues.

\subsubsection{Bahrain Population}

It had growth more than double between 1992 and 2011 where it increased from 516,458 to $1,195,020$ (CIO). Since there is a noticeable increase in the population in the Kingdom of Bahrain, the services and job opportunities have also increased which has encouraged a multicultural community and multiplicity of religions. However, this is also likely to lead to social problems. It is an axiomatically, that security and social problems are on the increase and in need of immediate and prompt solutions. The population age category 25:29 years old is the biggest category which is consisted of $14 \%$ of total population in 2011 census where $70 \%$ of this category is non-Bahraini (CIO), this normal outcome due to depending on foreign workforce in Bahrain. It is noticeable that most significant issues of safety and security also fall within that workforce category. This is because most of the security problems lie in the accumulation of these communities in certain areas. Moreover, due to the difference of culture, and lifestyle, there is a general lack of safety awareness among these communities and the importance of following the principles and rules of the Kingdom, so it's considered understudy with Bahraini group. It is worth mentioning that a large proportion of these workers are illegally forced to work in some businesses that are not fully controlled by the government. This in fact helps to increase the risk of them in both residential and commercial areas where they are concentrated. Following images show some cases which caused by foreign labors and occurred due to lack of safety precautions.

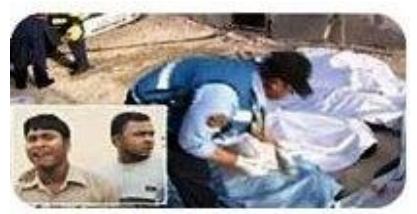

Photo 1: foreign labors victims by the fire in Riffa area

Source: Alayam newspaper-no.8449- Monday 28th may 2012

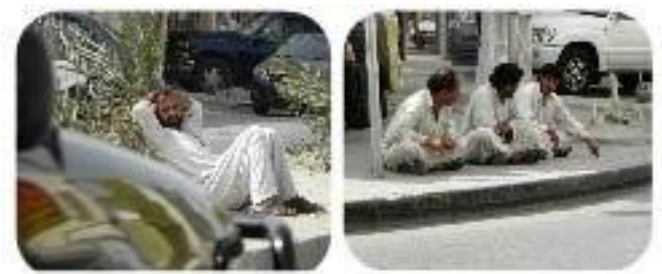

Photo 2: the foreign labors, where they are waiting in commercial roads to deal any job

\section{Source: Southern Governorate archive}
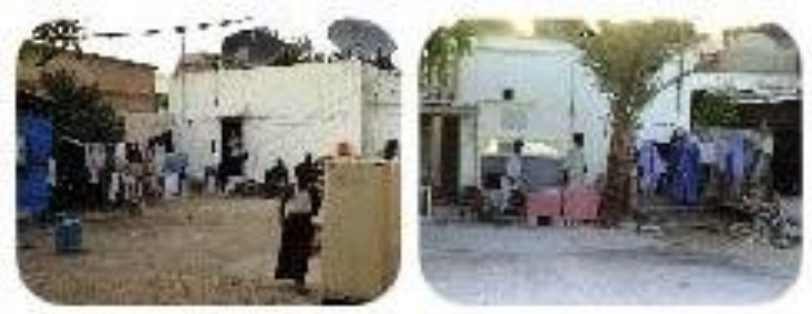

Photo 3: the foreign labors life style in neighborhood neglecting the respect to community

\section{Source: Southern Governorate archive}
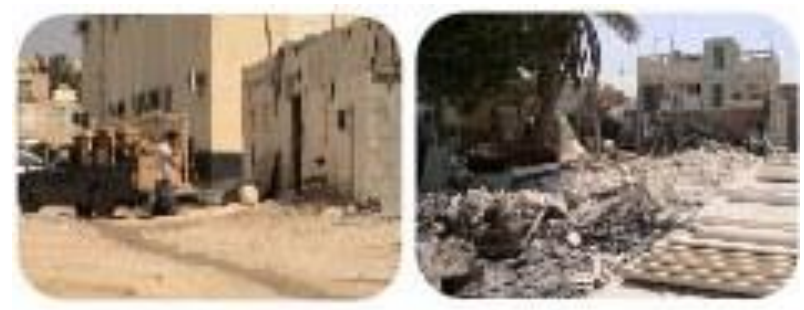

Photo 4: Foreign labors convert part of their old house to workshop in neighborhoods. Gypsum workshop and carpentry workshop, thus affect the defensibility of neighborhood.

\section{Source: Southern Governorate-Infrastructure book}

\subsubsection{Houses}

Houses in Bahrain are as old as the ancient civilizations that flourished here. From the remains of these prehistoric civilizations and an examination of the subsequent building styles over the centuries, it is evident that each period in history has been influenced by the previous. While absorbing some forms, and modifying others, a pure Bahrain style of architecture has emerged, which is quite unique; a style which was at its, peak in the late $19^{\text {th }}$ and early $20^{\text {th }}$ centuries. Each civilization has developed aspecific tiding, a style determined by the climate, economics and social customs etc.(Al-Oraifi, R. , 1989) Bahrainis lived historically in small houses made of local materials such as mud and stones. Afterwards, it developed into houses made of blocks. Today, after the laborers from different countries came to work and live in Bahrain, a new type of building has been created to accommodate them. Figure 2 shows the building type and the percentage of each in Bahrain. House building accounts for $72.7 \%$ of the total buildings in Bahrain, which is distributed as $12.5 \%$ for apartment 
buildings, $45.7 \%$ for private villas, $2.9 \%$ for garden villas, $8.0 \%$ for conventional house / housing villas, and $3.6 \%$ for traditional houses(CIO). The majority of Bahraini people live in private villas where they select the location of their villas, the neighborhood and the type of people who will share the common facilities with the owners. In addition, most have choices of villa interiors and exterior designs which reflect their personalities. The majority of expatriates live in apartment buildings and old traditional houses, which are estimated to account for a total of $22 \%$ of the total number of residential buildings. This shows an accumulation of them insuch housing, which may give an indicator of the need for attention to safety precautions for residential enterprises.Increase in the number of floors in residential enterprises increases the chances of crime (Newman, Creating Defensible Space, 1996). But it is the crime rate within apartments that is not affected by the increase of the number of floors. This increases the chances of the occurrence of crime in interior public spaces by increasing the number of floors dramatically (Newman, Creating Defensible Space, 1996)As the majority of buildings that are used for housing in Bahrain are not more than 3 floors, the crime rate is low in interior public spaces and the incidence of crime that often occurs within the residential apartments are larger than in the outside. Thus it can be assumed that most residential areas in Bahrain does not suffer from crime, but the problem lies in not taking safety precautions in residential buildings.Figure 3illustrates the percentage distribution of building age in each governorate according to the census of 2010. It is notable that the houses more than 25 years old are $15.2 \%$ and $18.5 \%$ and this type of houses have become attractive for the expatriates to live in. The major percentage of houses more than 25 years was in the capital and stands at $24.8 \%$. The Ministry of Housing and Ministry of Municipality Affairs and Urban Planning have sought to renovate or rebuilt the old houses so that the owners can live themselves instead of renting for the laborers, mixed with the original residents causing social problems.

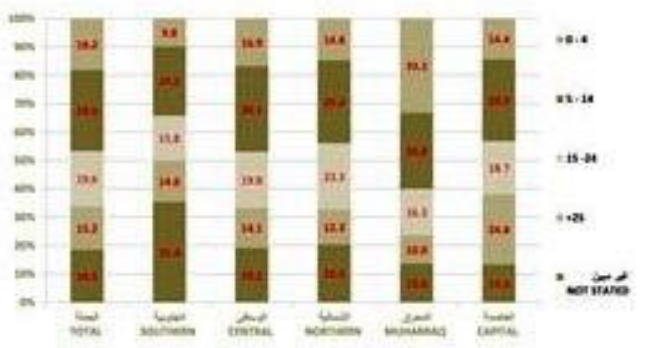

Fig 3: the percentage distribution of building by building age (by year) and governorate

\section{Source:http://www.cio.gov.bh/cio_ara/English/Publicatio ns/Census/Buildings14_2_2011.pdf}

\subsubsection{Road Network}

Road Network in Bahrain is characterized by narrow roads especially the Muharraq governorate, Capital governorate and Southern governorate. These roads, because of old planning approaches for the neighborhoods and residences are made even narrower by the people's behavior of parking the cars randomly on both sides of the roads. Roads around apartment buildings are narrowed by shades fixed for personal cars without license, and construction of high caps for the septic tanks. The streets are often poor in conditions and needs major improvement to be good enough to accommodate the pedestrians and even the disabled people. It was observed that these roads and traffic behave in Bahrain could be described by the photos (5) : (13)

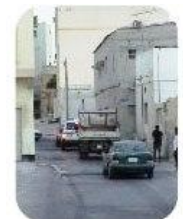

Photo 5 Photo 6

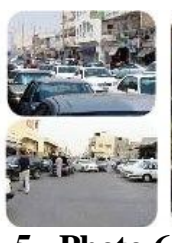

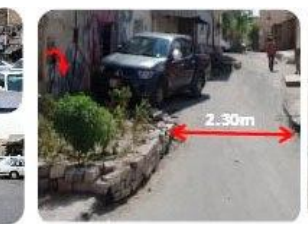

Photo 7

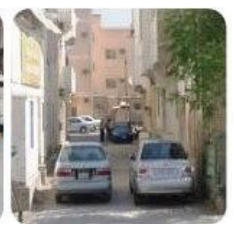

Photo 8
No sidewalk (all photos)

Narrow road which is not enough for two way traffic (photos 5, 7, and 8)

No vision angle in the intersection (photos 1 and 8)

No maintain of roads surfaces

Blocking the road by improper parking (Photo 6 and 8)

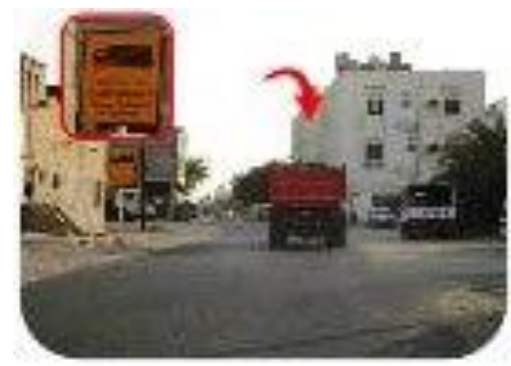

Photo9: Ignoring the traffic instruction signs, due to absent of monitoring systems and minimum fines of traffic Violation

Source: Trucks study-2013 Sothern Governorate

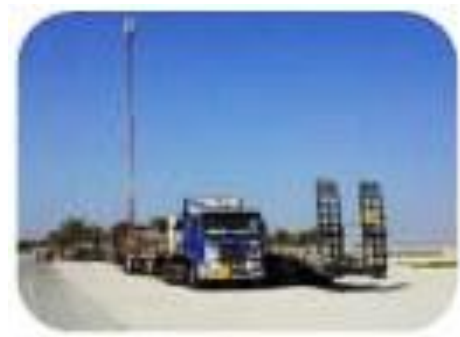

Photo 10: Due to smalls the fines of traffic Violation, trucks are parking wherever areas are available, without care of allowing or not. Parking near the public space affects negatively the image of public space.

Source: Trucks study -2013 Sothern Governorate 


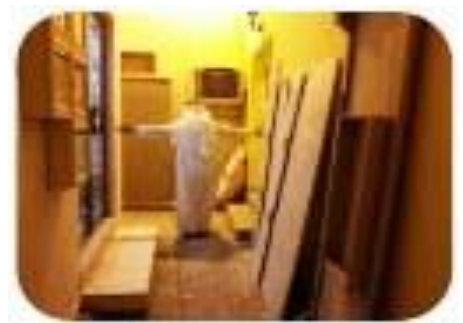

Photo11: illustrates narrow public road lead to many houses, which cause dangers in case of emergency. The firefighting and ambulance vehicle could not enter these areas.

\section{Source: author photography}

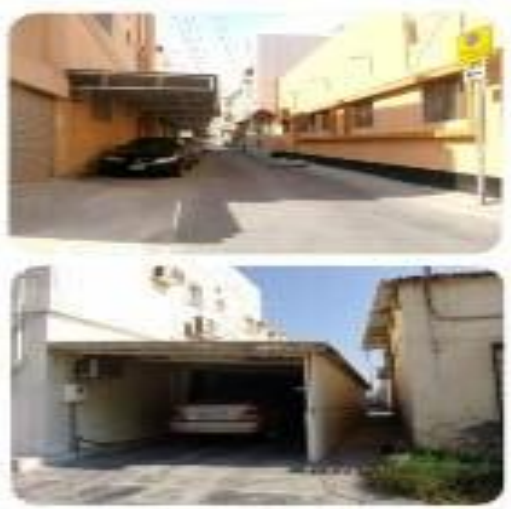

Photo12: illustrates blocking the roads by constructing a garage, with absent of municipality inspection.

Source: author photography

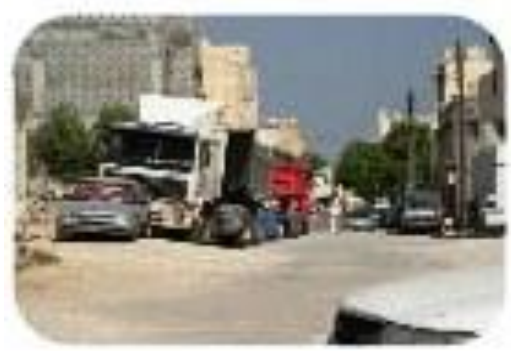

Photo 13: illustrates heavy trucks in local road at residential neighborhood; that affect the safety of residents.

Source: author photography

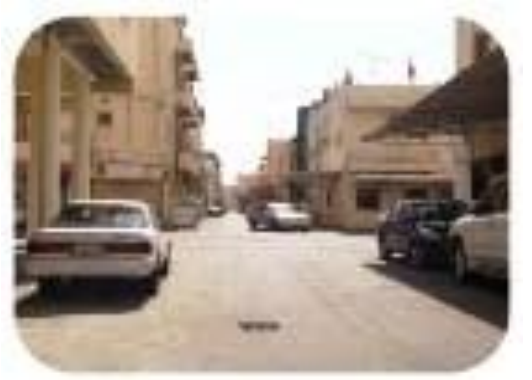

Photo 14: the difficulties faced by road users due to the occupancy of roads and intersections and lack of vision
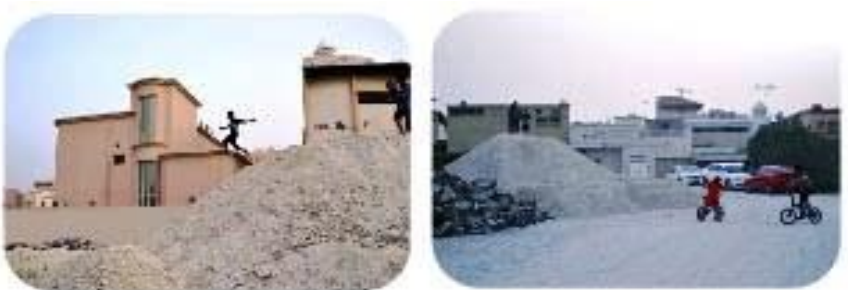

Photos 15 illustrate the lack of open spaces in neighborhood for children playing.

\section{Source: author photography}

\subsubsection{Threat Sources}

Threat Sources inBahrain are numerous and exist without being acknowledged. Although the most significant aspect of any public space is safety, there are a lot of public spaces exposed to such threat sources. It is known that if areas are known to be publicly unsafe, then people are unlikelyto frequent them. In Bahrain, there are only a handful of public spaces but they are also exposed potentail acts of vandalism although not so frequent. This is mpre so, if they exist in area sclose to low-income communities and socially deprived communities. There is no doubt that there exists a dire need to eliminate such threat sources if these publicspaces are to become great public spaces. The power the public spaces has, to revitalize communities must be employed for the benefit of the communities (Space, 2012)

Block no. 907 and 903 residential blocks in Riffa are in similar conditions; poor families of low education levels live near each other and their children play in public space in a dangerous way (photo 15) because of the unavailability of entertainment places such as gardens, walkways or clubs. This means those sample study communities lose safety of the spaces. As shown in Photo 16, the block 925 illustrates other types of non-safety aspects in the neighborhoods, such as the oil pipe line network which connects Saudi Arabia to Bahrain. This network crosses many areas, neighborhoods, roads and open spaces which threaten the safety of residential areas. In case of leakage or explosion of pipes of the network, these can lead to enormous problems and catastrophic environmental pollution. Morever photos (17:19) show other types of threats such as water pollution, waves threats, and air pollution

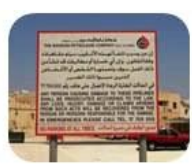

(A)

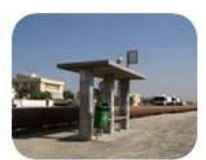

(B)

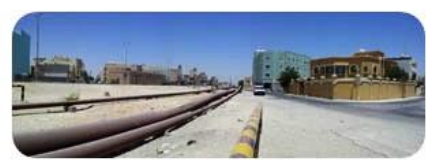

(C)
(A) Just instruction and warning board to prevent the pipe not the peoples (B) Bus stop is very close to the oil pipe, which cause dangers to the passengers $(C)$ The oil pipe is installed in which no barriers or pavement to prevent the cars to crush the pipe, which might cause awe some accident with huge fire

Photo 16 source of threat from oil pipe line network (Block 925, East Riffa, Bahrain)

Source: author photography

Source: author photography 


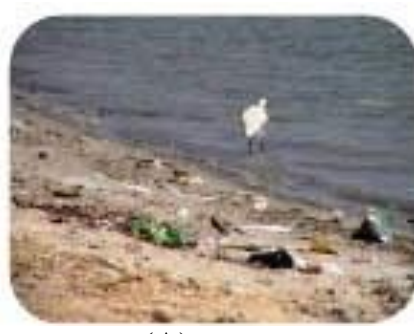

(A)

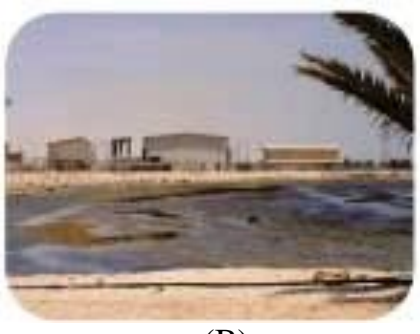

(B)
(A) Absent of beaches maintenance and cleaning which might hurt the people during swimming (B) Disposal of sewage into the sea water, which pollutes the coast and produce unpleasant odor

Photos 17 sources of water pollution threats in sites at Bahrain

Source: author photography

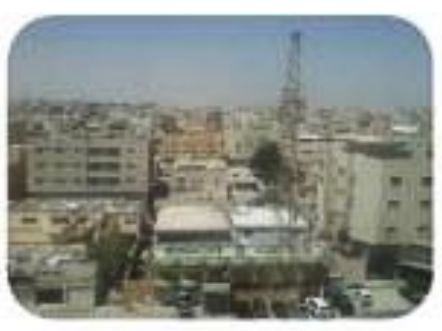

(A)

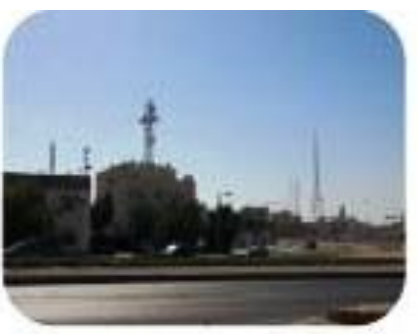

(B)
(A)High voltage electricity towers installed very close to residential houses, which might cause mainly psychological problems in addition to lymphatic leukemia (B)

Telecommunication towers are the Sources of electromagnetic waves in residential areas, which cause the brain caner

Photos 18 sources of waves threats in sites at Bahrain Source: author photography

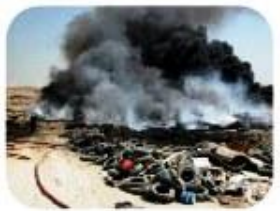

(A)

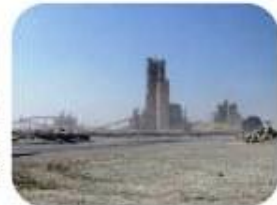

(B)

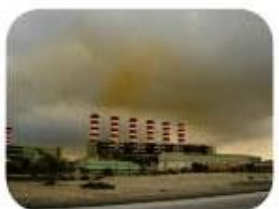

(C)
(A) Air pollution due to burning solid wests which cause health problems especially lungs cancer (B) Air polluation due ro raising the fumes of factories which pollute the resedential environment (B) Air pollution due to raising the smokes from chimneys of power generation station in industrial area which is close to residential areas

Photos 19 sources of air pollution threats in deferent sites at Bahrain

Source: author photography

\subsubsection{Environmental Issues}

Bahrain faces many problems in the areas of infrastructure and risk management. The output of government sector is low speed process to find the solutions for the current infrastructure problems. These problems simply can be categorized in terms of their planning, designing or social behavior. They affect security and safety levels in the neighborhoods; the drainage, the lighting, the foreign labors, the tracks and the heavy vehicles. There are also problems of old narrow roads which obstruct the emergency vehicles when they attempt to serve the old neighborhoods. The main problem occurs during the winter season. For a long time, the problem of rainwater has existed with no response from the authorities to solve it. When rains falls, mud ponds can be seen in areas coming under all the governorates causing traffic jams and problems of health for many of the residents. According to the civil aviation statistics,there is a possibility of changing the climate of Bahrain in the long term.In 2006, Bahrain faced heavy rain which reached up to $210 \mathrm{~mm}$ while the average was $15 \mathrm{~mm}$ to $70 \mathrm{~mm}$ (Climatology, 2011)which is three times more than the average, a lot of accidents happened in the roads, with the narrow roads having been closed, and water flowing inside old houses while some trees fell down. These reflect poverty of planning, design and infrastructure of cities. Photos (20), shows how the issues exist in the Southern governorate neighborhoods.
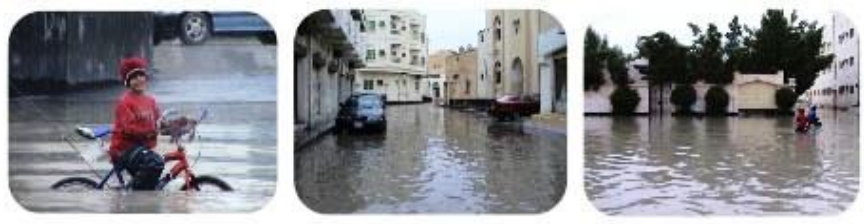

Photos 20 the absence of rain water drainage network in most residential areas

Rainfall in 2006- East Riffa 903

Source: Southern Governorate archive

\subsection{Survey Study}

To discover the issues and substantiate the arguments, a survey has been carried out by conducting a questionnaire. Following outlines the steps:

\subsubsection{Questionnaire Aims}

To give an opportunity to the residents to show their concerns and ideas related to raising the level of security in their residential neighborhoods. It allowed them to articulate how they perceived the threats could be reduced by adopting safety and security factors, also to define the security situation in Bahrain community, and to identify the factors that negatively affect the sense of security.

\section{3..2 Population and Sample of Survey}

The survey population of Bahrain was 1,195,020, according to the 2011 census, while sample size of 100 was taken randomly to cover most inhabitants of Bahrain in terms of 
gender, citizens and foreigners. The age group for this sample was between 25-35 years, where they constituted the average rate of the population pyramid for Bahrainis and the highest rate in the population pyramid for non-Bahrainis. Reviewed survey results for this age group were about 75\%.(Gorverment, 2009)

\subsubsection{Questionnaire Design}

The questionnaire was designed include a number of types of questions.It starting with questions related to general information. These were followed by questions related to analysis of opinions and facts. Further it included a number of Likert attitude scale questions and open-ended questions. The questions were intended to ascertain the feelings of the facts by the residents in the community, so that the possibilities and the need of applying defensible space design strategies in Bahrain.

\subsubsection{Survey Methodology}

Questionnaires were distributed in two ways; by social media and field interviews in some regions and governorates of the Kingdom. 110 were collected out of which a total of 70 samples were identified from the social media and 40 samples from the interviews. 4 of them were not satisfactory and 1 was ignored to make a sample comprised of a total of 100 .

\subsubsection{Data Finding and Discussion}

The result of the survey was analyzed after checking for the accuracy of the respondents. Then the missing or incomplete responses have been ignored.Finally, a statistical data was extracted to deal with each question. Results were shown in comparable table no. (1)

Result No. 1 shows that the highest age group was (25 -35) years old and accounted for $\mathbf{7 5 \%}$, while the second group (35-45) years old accounted for $\mathbf{1 7 \%}$. The lowest percentage was $7 \%$ for the age group more than 45 years of age. This age group classification is computable with the population pyramid of Bahrain whether Bahraini or non-Bahraini and reflecting the proportion.

Result No. 2 shows majority of the respondents live in flats about $72 \%$, while $19 \%$ live in government houses and $9 \%$ live in private houses. The house type is more defensible than flats exceeding six floors, because of the large number of residents in one building will share all the building facilities.(Newman, Creating Defensible Space, 1996). Majority of selected respondents were residents in flats in order to focus on the unsafe areas in Bahrain.

Result No. 3 shows that $33 \%$ strongly disagreed about the Bahraini planning and designs of the cities for not considering the risks involved in the possibility of any change of climate that could happen in the future. $33 \%$ disagreed on the capability of cities to withstand any natural disaster, while $20 \%$ remained neutral, $14 \%$ agreed and $0 \%$ strongly agreed.It is worth noting that the lack of city planning for natural disasters extends even to the absence of emergency plans to combat floods, and crisis management. Examples are the network of oil and electricity transmission lines that exist near residential areas and absence of any plans for dealing with emergencies in the event anything happens. Moreover, Bahraini people know the magnitude of the problem, but the responsible agencies are ignoring the problem for several reasons
Table 1: Questionnaire Summery findings

\begin{tabular}{|c|c|c|c|}
\hline$\#$ & Question & Answers & $\begin{array}{l}\text { \# of } \\
\text { Respondents }\end{array}$ \\
\hline \multirow{3}{*}{1} & \multirow{3}{*}{ Age of respondents } & $25-35$ & 75 \\
\hline & & $35-45$ & 17 \\
\hline & & more than 45 & 7 \\
\hline \multirow{3}{*}{2} & \multirow{3}{*}{$\begin{array}{l}\text { Building type of } \\
\text { respondents }\end{array}$} & Private House & 9 \\
\hline & & Gov. House & 19 \\
\hline & & Flat & 72 \\
\hline \multirow{5}{*}{3} & \multirow{5}{*}{$\begin{array}{l}\text { Do you think that the } \\
\text { planning of cities in } \\
\text { the Kingdom of } \\
\text { Bahrain initialize for } \\
\text { any natural disaster } \\
\text { (such as floods, } \\
\text { earthquakes or } \\
\text { hurricanes)? }\end{array}$} & Strongly agreed & 0 \\
\hline & & agreed & 14 \\
\hline & & neutral & 20 \\
\hline & & disagreed & 33 \\
\hline & & strongly disagreed & 33 \\
\hline \multirow{5}{*}{4} & \multirow{5}{*}{$\begin{array}{l}\text { Mixing the different } \\
\text { cultures in one } \\
\text { residential } \\
\text { neighborhood led to } \\
\text { poor relations has } \\
\text { caused the } \\
\text { emergence of } \\
\text { problems and } \\
\text { crimes? }\end{array}$} & Strongly agreed & 35 \\
\hline & & agreed & 32 \\
\hline & & neutral & 19 \\
\hline & & disagreed & 10 \\
\hline & & strongly disagreed & 4 \\
\hline \multirow{2}{*}{5} & \multirow{2}{*}{$\begin{array}{l}\text { Neighborhood you } \\
\text { live in is } \\
\text { characterized by }\end{array}$} & A safe Neighborhood & $43 \%$ \\
\hline & & Un safe Neighborhood & $57 \%$ \\
\hline \multirow{5}{*}{6} & \multirow{5}{*}{$\begin{array}{l}\text { Availability of } \\
\text { emergence access in } \\
\text { neighborhood }\end{array}$} & Strongly agreed & 53 \\
\hline & & agreed & 25 \\
\hline & & neutral & 15 \\
\hline & & disagreed & 5 \\
\hline & & strongly disagreed & 2 \\
\hline \multirow{5}{*}{7} & \multirow{5}{*}{$\begin{array}{l}\text { The presence of } \\
\text { foreign workers and } \\
\text { other nationalities in } \\
\text { the neighborhood } \\
\text { where you live? }\end{array}$} & Strongly agreed & 14 \\
\hline & & agreed & 20 \\
\hline & & neutral & 24 \\
\hline & & disagreed & 14 \\
\hline & & strongly disagreed & 28 \\
\hline \multirow{5}{*}{8} & \multirow{5}{*}{$\begin{array}{l}\text { The presence of } \\
\text { heavy traffic } \\
\text { movement for } \\
\text { vehicles and } \\
\text { pedestrians in the } \\
\text { neighborhood where } \\
\text { you live? }\end{array}$} & Strongly agreed & 16 \\
\hline & & Agreed & 25 \\
\hline & & Neutral & 31 \\
\hline & & Disagreed & 21 \\
\hline & & Strongly disagreed & 7 \\
\hline \multirow{5}{*}{9} & \multirow{5}{*}{$\begin{array}{l}\text { What do you think } \\
\text { the level of adequate } \\
\text { lighting in the } \\
\text { neighborhood where } \\
\text { you live? }\end{array}$} & Very inadequate & 30 \\
\hline & & Not enough & 37 \\
\hline & & Neutral & 25 \\
\hline & & Sufficient & 5 \\
\hline & & Very adequate & 3 \\
\hline \multirow{5}{*}{10} & \multirow{5}{*}{$\begin{array}{l}\text { Cause of insecurity } \\
\text { in the neighborhood } \\
\text { where you live (in } \\
\text { the absence of a } \\
\text { sense of security)? }\end{array}$} & Disused house & 10 \\
\hline & & Inadequate of lighting & 21 \\
\hline & & Traffic & 17 \\
\hline & & No lighting & 21 \\
\hline & & Foreign labors & 31 \\
\hline
\end{tabular}




\begin{tabular}{|c|c|c|c|}
\hline \multirow{5}{*}{11} & \multirow{5}{*}{$\begin{array}{l}\text { Available squares } \\
\text { (Open space) in the } \\
\text { neighborhood you } \\
\text { live in and can } \\
\text { control more of the } \\
\text { house of the vacuum } \\
\text { if the Note any } \\
\text { activity in it? }\end{array}$} & Strongly agreed & 13 \\
\hline & & Agreed & 35 \\
\hline & & Neutral & 24 \\
\hline & & Disagreed & 17 \\
\hline & & Strongly disagreed & 11 \\
\hline \multirow{2}{*}{12} & \multirow{2}{*}{$\begin{array}{l}\text { Do you think } \\
\text { carefully about a } \\
\text { factor of safety and } \\
\text { security for the } \\
\text { selection of the } \\
\text { neighborhood where } \\
\text { you live and who are } \\
\text { neighbors? }\end{array}$} & Yes & $97 \%$ \\
\hline & & No & $3 \%$ \\
\hline \multirow{5}{*}{13} & \multirow{5}{*}{$\begin{array}{l}\text { The existence of the } \\
\text { meetings and youth } \\
\text { rallies in the } \\
\text { neighborhood where } \\
\text { you live? }\end{array}$} & Strongly agreed & 19 \\
\hline & & Agreed & 29 \\
\hline & & Neutral & 32 \\
\hline & & Disagreed & 11 \\
\hline & & Strongly disagreed & 9 \\
\hline \multirow{5}{*}{14} & \multirow{5}{*}{$\begin{array}{l}\text { There is one or more } \\
\text { police patrol in the } \\
\text { neighborhood where } \\
\text { you live you sees on } \\
\text { a daily basis to } \\
\text { provide security? }\end{array}$} & Strongly agreed & 16 \\
\hline & & Agreed & 21 \\
\hline & & Neutral & 23 \\
\hline & & Disagreed & 31 \\
\hline & & Strongly disagreed & 9 \\
\hline \multirow[b]{2}{*}{15} & \multirow{2}{*}{$\begin{array}{l}\text { Do you feel secure } \\
\text { while using the } \\
\text { streets of the } \\
\text { neighborhood where } \\
\text { you live? }\end{array}$} & Yes & $20 \%$ \\
\hline & & No & $80 \%$ \\
\hline \multirow{4}{*}{16} & \multirow{4}{*}{$\begin{array}{l}\text { In your opinion, the } \\
\text { streets must be safe } \\
\text { by }\end{array}$} & Car park needs & 112 \\
\hline & & $\begin{array}{l}\text { Attractive activities } \\
\text { needs }\end{array}$ & 21 \\
\hline & & Humps needs & 46 \\
\hline & & Traffic light needs & 21 \\
\hline \multirow{4}{*}{17} & \multirow{4}{*}{$\begin{array}{l}\text { How would you } \\
\text { describe the streets } \\
\text { of the neighborhood } \\
\text { where you live? }\end{array}$} & local road & 66 \\
\hline & & commercial road & 22 \\
\hline & & walkway & 7 \\
\hline & & Highway & 5 \\
\hline \multirow{5}{*}{18} & \multirow{5}{*}{$\begin{array}{l}\text { Can distinguish } \\
\text { strangers in the } \\
\text { neighborhood as a } \\
\text { result of the strength } \\
\text { of social cohesion in } \\
\text { the neighborhood } \\
\text { where I live? }\end{array}$} & Strongly agreed & 20 \\
\hline & & Agreed & 20 \\
\hline & & Neutral & 32 \\
\hline & & Disagreed & 19 \\
\hline & & Strongly disagreed & 9 \\
\hline \multirow{3}{*}{19} & \multirow{3}{*}{$\begin{array}{l}\text { Any idea you prefer } \\
\text { more in the planning } \\
\text { of cities and } \\
\text { villages? }\end{array}$} & Compound style & 28 \\
\hline & & $\begin{array}{l}\text { Security checkpoint } \\
\text { around }\end{array}$ & 36 \\
\hline & & Open style & 36 \\
\hline
\end{tabular}

Result No. 4 shows the opinions of the respondents about negative effects of mixing people with different cultures in one neighborhood. This kind of mixing has already led to poor relations and has reduced the feeling of security among residents. However, on this question, 23\% strongly agreed,
$32 \%$ agreed, 25 remained neutral, while $16 \%$ disagreed, and $4 \%$ strongly disagreed.Today the world has become like a small country because of modern transportations and communications. Therefore a lot of families leave their home countries to acquire good life styles, thus different ethnicities mixing is a common occurrence.(Mixing different cultures of foreign laborers with the original residents of Bahrain in neighborhoods indicate that a dangerous problem could happen in future with the increase of the numbers of laborers. Also its effect on the cohesion of the social relationships and on national unity and civilian security rather than the other side's which effect on them directly or indirect (Khalifa, 2009) this means that there is a perception that Bahrain society is socially threatened.

Result No. 5 shows the respondents opinions of describing their neighborhoods. $43 \%$ of the respondents described their neighborhoods as being safe, while $20 \%$ described having too many car accidents. $22 \%$ expressed that neighborhoods have social problems with neighbors and $15 \%$ complained about robberies. Thus, in total $57 \%$ unsafe neighborhoods. This is because a lot of cultures and foreign illegal laborers live in the same neighborhood. The idea of defensible space design is that crime and delinquency can be easily taken care through the design of facilities and methods of distribution services and the design of social harmony.

Result No. 6 shows the difficulties of access for emergency and security cars in the old neighborhoods or cities. On this issue, 53\% respondents strongly agreed, $25 \%$ agreed, $15 \%$ remained neutral, while 5\% disagreed, and $2 \%$ strongly disagreed. Participants mentioned a number of old neighborhoods in some cities. For example, they referred to old neighborhoods in Manama, Muharraq, and in East Riffa, which were characterized by narrow roads and irregular urban tissues without any developments. Respondents indicated answers to the inefficiency of the road network in various areas of the old residential areas in Bahrain because of the lack of appreciation of the following factors; Land use and transportation system, assessment for short and longrange planning, public policy, environmental analysis and plan implementation.

Result No. 7 shows sample of opinion about the availability of foreign laborers in the neighborhoods. Here, $14 \%$ strongly agreed. Most of them live in an old neighborhood in Muharraq and Riffa where there are many foreign laborers mixed with Bahraini families. While $20 \%$ agreed, $24 \%$ remained neutral, $14 \%$ disagreed and $25 \%$ who live in modern cities strongly disagreed.In these old cities, a lot of laborers and low income people live, because the owners are trying to invest through their buildings by renting them to laborers who accept poor or bad conditions of residential units while the owners lived in a new city or a town with comforts and good conditions. It can thus be deduced that some of the social security problems of neighborhoods arise from the behaviors of the house owners. 
Result No. 8 shows the opinions of respondents for the traffic and pedestrian movements in the neighborhoods. Here, 16\% strongly agreed that too much traffic existed. $25 \%$ of others also agreed, $31 \%$ remained neutral while $21 \%$ disagreed while $7 \%$ strongly disagreed.Car movements depend on where people live. As we know, the old neighborhoods have narrow roads which do not allow vehicles to pass through the neighborhoods. Thus, this allows for pedestrians to move freely between the houses. In the modern cities like Hamad Town and Arad, the city is characterized by the wide road network in front of the houses that led the residents back to the house zone, because the outdoor zone has been a dangerous zone. It is suggested that Bahrain should look at the idea of areas for walking without the cars being present. Inother words, this means the development of a good network of public transport facilitating access to neighbourhoods to which people can walk. It will reduce the enormous number of cars in Bahrain which seems to continue to incrase alarmingly. In Bahrain however, encouraging people walk and not to use their cars (wikipedia, Car_free_walking, 2013) is an ardoud task. Fisrt of all, there is the climate wjich is not helpful Secondly, the cars are affordable. More importantly however, fuel is the cheapest and it is impossible to take away the temptation people have in getting onto the car. However, with a $50 \%$ population being expats who are used to walking in their own countries, this should be an opportunity that should be explored.

Result No. 9 shows the respondent's answers to the question of adequacy and efficiency of lighting in the neighborhood spaces or road networks. For this question, $30 \%$ said that it was very inadequate and most participants mentioned delays in maintenance. $\mathbf{3 7 \%}$ or the majority of the participants said that lighting was not enough and there was no assessment for lighting efficiency. 25\% remained neutral, while $5 \%$ said sufficient and $\mathbf{3 \%}$ said very adequate.Street lighting systems require ongoing maintenance which can be classified as either reactive or pre-emptive.Strengthening the argument, many respondents said that good outdoor lights improve visibility. Without doubt, they contribute to safety, and a sense of security because any vandals canbe seen and get caught.More over, good lights will also reduce glare and improve the general appearance of an area.

Result No. 10 shows the respondents' assessment of feeling unsafe in the neighborhoods. They clarified some of the reasons with different percentages. For example, $\mathbf{1 0 \%}$ said that disused houses in the neighborhoods were the main reason for the lapse in public security. $\mathbf{4 2 \%}$ of the respondents commented regarding the most important service; Lighting, more specifically, the lack of adequate lighting. $17 \%$ commented about traffic issues in the neighborhood and the entry of heavy trucks in addition to the number of cars increasing yearly. Increased investment in the building of car parks has contributed to this while $\mathbf{3 1 \%}$ of dwellings of the foreign laborers in some neighborhoods are also a factor. The idea of homogeneity is an important dimension that should be considered. Homogeneity means the ability of urban design to provide residential areas that are homogeneous internally and externally. This means internally in terms of social structure and age groups, and externally with the surrounding urban environments.(Dalia Ibrahim Abdul Razak, Majdi Mohammed Radwan, Azza Mohamed Djaas, 2005)

Result No. 11 shows the availability of open spaces in the neighborhoods as one aspect that contributes to sense of security and safety. A good neighborhood design can provide a neutral surveillance by the residents' themselves.Here, $\mathbf{1 3 \%}$ strongly agreed, $\mathbf{3 5 \%}$ agreed. Most people lived in Riffa and Hamad town. 24\% remained neutral, while $\mathbf{1 7 \%}$ disagreed and $\mathbf{1 1 \%}$ strongly disagreed. The participants lived in the old neighborhood in Muharraq in block No. 216 and East Riffa Block Nos. 903,905,907 and 909.Most open spaces currently available in the neighborhoods were used for car parking or for heavy trucks of some companies, pickups and private cars. This threatens the residents of the neighborhoods by creating undesirable commercial and social places that relate to trucks with outsiders moving in and out at various times of the day.

Result No.12 shows the respondents assessment about 'caring about neighbors and neighborhood selection' as an important aspect of decisions with regard to housing. Neighborhood is a daily shared space with all its facilities used by people who live around and share it with the intention to succeed in creating sustainable, secure and socially rich environments.For this question, 97\% said "yes" they cared about a selected neighborhood after the security crises. 3\% said "No" it is not an important issue to them.It is noted with great interest that the respondentswho commented on the importance in choosing a neighborhood that they will live, is based on security and social cohesion and the lack of crimes and the availability of health services, education and other trades.

Result No. 13 shows the responses to the question about youth meeting and gathering in the neighborhoods for which the. $\mathbf{1 9 \%}$ respondents strongly agreed while $\mathbf{2 9 \%}$ agreed, $32 \%$ remained neutral and did not worry about where they lived in new cities or new neighborhoods. For example, Hidd, Muharraq, Riffa, Safrah and Zallaq are noted as safe neighborhoods. $11 \%$ disagreed and $\mathbf{9 \%}$ strongly disagreed while they lived in old cities with a lot of foreign laborers, a lot of investment buildings, no car parking, no open spaces and less public parks.It is worth mentioning that there is a lack of young people in some residential areas. Here the issue is the aging neighborhoods which affect the distribution of housing and services for citizens with a family of small and medium-sized populations.It is intended to relate neighborhoods to family size and type (Newborn marriage - married with children - singles- Older), educational level and cultural heritage, and is a kind of social cohesion need.(Dalia Ibrahim Abdul Razak, Majdi Mohammed Radwan, Azza Mohamed Djaas, 2005)It is necessary to develop a sense of community and generate a sense of responsibility and belonging to the urban environment. That is to sustain life in the neighborhood where young people with different daily exercise opportunities provide a greater sense of security to the neighborhoods. 
Result No. 14 shows the availability of police patrols daily in neighborhoods to provide public security. $16 \%$ of the respondents answered as strongly agree, $\mathbf{2 1 \%}$ agreed, $\mathbf{2 3} \%$ was neutral, $\mathbf{3 1 \%}$ disagreed and $\mathbf{9 \%}$ strongly disagreed.We can provide security balance by locating police or cameras in neighborhoods or cities at government centers or VIP villas and offices.A number of respondents indicated that there are other factors that help create safe environments for the users as a need. For example, locating increased parking bumps and the presence of police patrols in the streets of residential neighborhoods could also enhance sense of security in neighborhoods.

Result No. 15 shows that $80 \%$ of the respondents feel not secure in streets in their neighborhoods. The Automobiles are one of the reasons. The modern cities are planned to provide wide roads and they often run in front of houses. In such situations, residences cannot establish contact directly with neighborhood environments because of security reasons.20\% of the participants feel secure because they live in Muharraq, Qalali, Busaiteen, Hidd, Nabi Saleh Island, Sitra and Riffa where the city is characterized by narrow lanes and roads and there are opportunities for pedestrians to walk freely and securely with children and adults.

Result No. 16 shows the respondent's opinions about providing safety in roads by some factors which affect the neighborhoods. $12 \%$ referred to car parking needs to organize and operate road traffic very well. $\mathbf{2 1 \%}$ referred to attractive activity space as one of place making for gathering and control. $46 \%$ at the highest percent suggested providing humps in roads to reduce driving speed. $21 \%$ insisted on traffic light needs to operate the road network. Younger generations of drivers have grown up with the in-car safety technologies that are now seen as standard. They are comfortable with these, which add to this feeling. But at the same time, people clearly want more done to monitor the behavior of other drivers on the roads, who they feel pose a risk to them due to perceived bad driving habits." (Gifford, R. 2011), and (RAC, t. d. 2012).

Result No. 17 shows the distribution of road types as experienced by people where participants live. The majority was identified as local road type which amounted to $66 \%$ percent. This reflects the real image of Bahraini planning and designing approach. Often, the arrangement of new houses locates the main gate of the house directly facing the road. The safety distance from traffic in these situations is normally from 1-3 m only which is not enough for adults or children. While the others identified $\mathbf{2 2 \%}$ as commercial roads, $\mathbf{7 \%}$ as walk ways and $\mathbf{5 \%}$ highways. A good complete street must cater to all users and must take on a variety of forms. This result does not show that and it is clear that factors such as right-of-way and street-side activities are absent. Even if they exist by law, right of way is not practiced and this is a serious hazard to walkers. The basic principles of street design such as pedestrian accessibility and sensitivity to local areas must be employed to create public space.(Bhatt, 2011)
Result No. 18 shows the respondents assessment of the presence of strange visitors in the neighborhoods. $\mathbf{2 0 \%}$ strongly agreed that their neighborhood design in a way made contact with automobiles and outsiders visually without intervening areas and spaces. Here, $20 \%$ agreed, while $\mathbf{3 2 \%}$ remained neutral, which is the major category, 19\% disagreed and 5\% strongly disagreed.The visual contact with the outdoor space is very important for residents particularly the families who have got children. Today the presence of foreign laborers around neighborhoods has become a serious social phenomenon and the responsible people in the government work slowly to resolve these issues while this type of social problems should be resolved very fast.Most respondents expressed their ability to know when there are strangers in the neighborhood through personal relationships. This reflects the extent of communication and social cohesion and enables self-censorship of the neighborhood.

Result No. 19 shows the respondent's opinions about neighborhood type. $\mathbf{2 8 \%}$ of the respondents preferred compound style, which has an enclosure by a boundary wall with a main entrance with security facilities. This type makes the neighborhood more secure and safe especially from strangers and visitors, but may contribute to reduced social relationships between each unit in the neighborhood. $36 \%$ of the participants preferred security checkpoints around, which means that in case of emergency, it can be activated any time. $36 \%$ preferred live in open neighborhood style, may be because they become familiar with this style.Most respondents preferred two types of housing types; security checkpoint being around and the open style in spite of the fact that the compound style type offers more quality characteristics of the neighborhood.

Result No. 20 shows the respondents opinions about some factors which affect the safety in the neighborhoods in the order of priority to them.The factors are: Design of House, Narrow roads, Distribution of services, Collapsed and disused houses, Distribution of lighting, and Height of building.

The major category for the first priority referred to 'collapse or disused houses which amounted to $25 \%$. Theparticipants said that it affects the feeling of safety in the neighborhoods, while the major category for last priority was for buildings height which amounted to $39 \%$.

\section{RECOMMENDATIONS}

This research outcome some recommendations to be considered to develop the current criteria in urban planning and regulations to improve the neighborhood environments with maximum ability of space to construct self-defense; to have defensible urban spaces by themselves, Such Recommendation as listed below:

- Createworkers' cities in all governorates of the Kingdom of Bahrain, as a radical solution to the social and security problems resulting from the current situation of foreign workers in residential areas. These labor cities can provide all the basic 
services for the workers with a reasonable fee charged to companies on the basis of their economic situation.

- Re-examine the construction and development regulations for the development of towns and villages in terms of zoning or land use and detailed conditions of their own facilities and the urban environment of the surrounding spaces, road networks, security, trade, health, education, religious, investments and other services buildings to find a balance in the urban space services after appearance of some problems.

- Acquisition in the public interest and the creation of multi-functional spaces, for example:

a. Instead improve public transportation, Create Public car parks as a radical solution facing the challenges with the increase of private cars, especially in areas that are zoned as residential and investment areas. This will reduce all types of excesses that happened because of misbehavior of the residents who have no opportunities to behave in a legal way according to their life styles. Many of the issues arise due to the misconception of the future user needs among the decision makers.

b. Assess and develop the efficiency and suitability of the road network patterns in the cities, villages and neighborhoods to be safely used. Also ensure that there is a clear route for the entry of vehicles of civil defense and ambulances in case of emergency.

c. Increase the green areas that contribute to creating vital neighborhoods by attracting people to gathering. Through this, the spatial feeling of belonging to the neighborhood with responsibility of security will be implanted.

- Special regulationsfor the natural environmental changes should be considered by taking care of urban planning and design of all types of facilities. Ensure that proper safety measures are used that can cope with changing environmental conditions as a safety precaution.

- Devise radical and quick solutions for the following threats from sources in urban spaces as proposed listed below:

a. Oil pipeline network in the residential areas should be re-rooted according to the current situation of the housing growth, because they are becoming dangerous for the residences.

b. Create a plant for recycling tires and scrap rubber to protect the environment from serious damage from misuse or storage.

c. The random sites of production and distribution of electricity in residential areas should be re-examined.

d. Commitment tothe standards ofthe global environmentin the productionand distribution of electricity andthe risks associated withemissionsfromthese stations'productivity andsub-transmission lines andspacesthroughits safety zone buffers.

e. The formation of a network production and distribution of electricity on a regular basis which considers the safety distances in the planning of modern cities.

- Establish a commercial transport station (Transit Trucks Stop) to ensure that commercial trucks can enter residential areas or come near public facilities and urban landmarks in the Kingdom of Bahrain without crossing residential neighborhoods.

- Periodic assessment is done to develop the existing rules regarding needs and phenomenon.

- Design a framework for place making by integration in planning.

- Public involvement is one of the most significant aspects of contemporary planning. Public involvement brings to the forum the perspective of the residents which can help recognise and give expression to people's needs early in the process. This will also facilitate the implementation of projects by the practice of Advisory committee (Bahraini Majalees). Publoic participation can inlcude professionalpresentations and disussions (such as Bahrain tosabah /Radio Program and Ana Bahrain TV program), other public forums and seminars. They can be facilitated by newspaper articles and discussion through the media. It is advisable to organise site tours, small community meeting and surveys to ascertain people's openions.

- Re-design open spaces in the neighborhoods by studying the number of entrance and exits, lanes, roads, open spaces, layouts of buildings and other elements that affect the safety and security of the neighborhoods.

- Fast treatment for disused houses that become places for the gangs and thugs to gather creating unbalanced social tissues and become undesirable places for the residence.

- Study neighborhood behavior for all needs.

- Caring about public services maintenance

\section{REFRENCES}

[1] Al-Oraifi, R. (1989). Bahrain Heritage Series Architecture of Bahrain. Manama: Al Oraifi Gallery.

[2] Bacon, E. (1969). New Urbanism. Retrieved July 2, 2012, from www.newurbanism.org: www.newurbanism.org

[3] Bahrain, G. (2010). Central Information Organisation. Retrieved 6 30, 2012, from http://www.cio.gov.bh

[4] Bhatt, H. (2011, 12). library. Retrieved 11 26, 2013, from Institute for Transportation and Development: http://www.itdp.org/documents/BetterStreets111221 .pdf 
[5] Climatology, S. (2011, March 16). 10 Years Climatic Information. Bahrain Civil Aviation Affairs . Muharraq, Bahrain Int'l Airport: Meteoroloigcal Directorate.

[6] D.Crowe, T. (2000). Crime Prevention Terough Enviromental Design (2nd ed.). Woburm, Massachusetts: Butterworth-Heineman.

[7] Dalia Ibrahim Abdul Razak, Majdi Mohammed Radwan, Azza Mohamed Djaas. (2005). Architectural factors affecting the achievement of security in residential areas. 6th Internaional Architectural Comference. Asyout: Asyout University,Engineering College.

[8] Gifford, R. (2001). Environmental Psychology Principles and Parctice (3rd ed.). Canda: Optimal Books.

[9] Gorverment. (2009). Publications Statistical. Retrieved 11 25, 2013, from Central Information Organization:

http://www.cio.gov.bh/CIO_ARA/English/Publicati ons/Statistical\%20Abstract/ABS2011/Ch2/G3.pdf

[10] Governorate, S. (2012). Narrow Road Networks in Southern Governorate. Eng. Affairs Section. Awali: Services and Development Dirctorate.

[11] Governorate, S. (2005, May). Southern Governorate Infrastructure Project. Southern Governorate Infrastructue Survey , 1 . Awali: Services \& Development Programs Directorate.

[12] Governorate, S. (2012). Tracks Entry and parking in Residential Area. Eng.Affairs Section. Awali: Services and Development Dirctorate.

[13] Khalifa, N. (2009). Khal Al-Moharraqe byna Althabat wa Al tagyeer. (1. s. edition, Ed.) Manama: Al Raja Printing Press.

[14] Litman, T. (2011, June 17). Retrieved March 2, 2013, from Victoria Transport Policy Institute: www.btpi.org

[15] Makarova, E. (2009). Elena Makarova, MFT . Retrieved from Psychotherapy in Palo Alto, South Bay and Mid-Peninsula http://elenamakarova.com/five_needs/

[16] Marcus Felson,Rachel Boba. (1947). Crime and Everyday Life (4th ed.). Thousand Oaks, California: Sage.

[17] Newman, O. (1996). Creating Defensible Space. Washington,D.C.: Center for Urban Poicy Research.

[18] Newman, O. (1972). Defensible Space Crime Prevention Through Urban Design (1st ed.). New York: Collier Books.

[19] Newspaper, A. (2012). Death of 10 Asian Labors. Alayam Newspaper (8449), 1.

[20] RAC, t. d. (2012). RAC Report on Motoring. United Kingdom: Rosanna Spero.

[21] Remy, M. (2013). crimtheory/newman. Retrieved March 2, 2012, from http://www.criminology.fsu.edu/: http://www.criminology.fsu.edu/crimtheory/newman .htm
[22] Space, P. f. (2012, April 9). pps. Retrieved from http://www.pps.org/blog/cynthia-nikitin-southafrica/ Retrieved on 9-4-2012: http://www.pps.org

[23] wikipedia. (2013, 3 24). Car_free_walking. Retrieved 11 25, 2013, from wikipedia: http://en.wikipedia.org/wiki/Car_free_walking

[24] wikipedia. (2013, 10 7). Defensible_space_theory. Retrieved 11 25, 2013, from wikipedia: http://en.wikipedia.org/wiki/Defensible_space_thero $\mathrm{y}$

[25] Wolfer, L., Baker, T., \& Zeezza, R. (1999). Proplem-Solving Policing Eliminating hot spots. Sydney: FBI Enforcement Bulletin.

\section{BIOGRAPHIES}

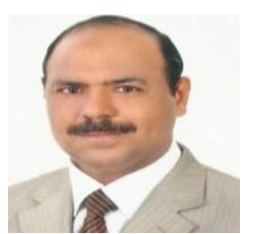

Ashraf Mohamed Soliman, Ph.D. is The Chairman of Interior Design Department; at KU, Bahrain, and assisstant professor of urban planning at Minia University, Egypt. His research interests, practices, and teaching are urban planning, architectural design, and computer applications in architecture and urban planing. He received his Ph.D. in GIS \& Urban Planning from Slovak University of Technology in Bratislava. Dr. Ashraf is an expert of urban and rural planning at physical planning Authority of Egypt. Egyptian Engineering Syndicate accredited Dr. Ashraf as consultant engineer in urban planning filed. He prepared many urban planning projects, such as land subdivision, strategic master plan, and detailed master plan of many cities and villages in Egypt.

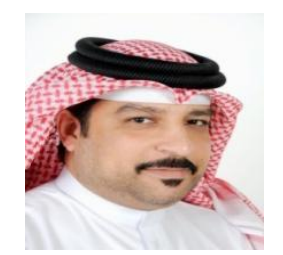

Hamad Juma Al- Fazari, M.Sc. is the Head of Engineering \& projects affairs section, Southern Governorate, Bahrain. Certified Coach - The Royal Academy of Police. Interested in Arctitecture Engineering, urban planning, security planning and services distribution to design balanced community. 